\title{
Audit Pengembangan Perangkat Lunak Menggunakan Metode Capability Maturity Model Integration Level 3
}

\author{
Arief Deswandi ${ }^{1}$, Barda Hudaya ${ }^{2}$ \\ 1,2Institut Teknologi dan Bisnis Ahmad Dahlan (ITB Ahmad Dahlan) \\ Jl. Ciputat Raya No.77, Cireundeu, Kec. Ciputat, Kota Tangerang Selatan, Banten 15419 \\ e-mail: 'arief.deswandi@itb-ad.ac.id; 2b4rd4.hoedaya@gmail.com
}

\begin{abstract}
Abstrak
Dalam proyek pengembangan perangkat lunak yang baik harus memiliki hasil dengan kualitas yang sesuai dengan kebutuhan pengguna dan juga tepat waktu sesuai dengan jadwal yang telah ditentukan. Kualitas produk perangkat lunak yang dikembangkan menjadi sangat penting bagi perusahaan pengembang perangkat lunak. Tujuan dari penelitian ini adalah untuk menganalisa masalah-masalah serta mengukur tingkat kematangan tentang kemampuan perusahaan selama proyek pengembangan berlangsung, terutama apabila perusahaan dengan sumber daya terbatas akan merasa kesulitan untuk meningkatkan kualitas perangkat lunak yang dihasilkan. Dalam penelitian ini akan digunakan metode Capability Maturity Model Integration (CMMI) level 3 yang merupakan pendekatan model dalam menilai skala kematangan sehingga dapat diketahui pada area proses mana saja yang telah memenuhi standar dan area proses mana yang masih belum memenuhi standar. Untuk melakukan penilaian digunakan SCAMPI-C dengan PST Tool pada 5 (lima) area proses pada CMMI level 3. Penilaian didasarkan pada kuesioner dan pengamatan dokumentasi proyek pada proses pengembangan perangkat lunak yang juga mendukung proses perbaikan. Penilaian kemudian dianalisis menggunakan Analisis Pareto untuk menentukan prioritas perbaikan. Proses pengembangan perangkat lunak yang sudah baik dari 5 (lima) area proses yang dianalisa adalah pada area proses OPD (Organizational Process Definition), OT (Organizational Training), dan PI (Product Integration). Sedangkan area proses yang belum memenuhi standar CMMI dan perlu diperbaiki secara skala prioritas terdapat pada area proses OPF (Organizational Process Focus), dan $R D$ (Requirement Development) dengan nilai kumulatif 44\% untuk OPF dan 68\% untuk RD.
\end{abstract}

Kata kunci: Pengembangan Perangkat Lunak, Capability Maturity Model Integration, Analisis Pareto

\begin{abstract}
In a good software development project must have results with quality that suits the needs of users and also on time according to a predetermined schedule. The quality of software products being developed becomes very important for software development companies. The purpose of this research is to analyze the problems and measure the level of maturity of the company's ability during the development project, especially if the company with limited resources will find it difficult to improve the quality of the software produced. This research will use level 3 Capability Maturity Model Integration (CMMI) method which is a model approach in assessing the maturity scale so that it can be known which process areas have met the standards and which process areas still do not meet the standards. To do the assessment used SCAMPI-C with PST Tool in 5 (five) process areas at CMMI level 3. The assessment is based on questionnaires and observations of project documentation on the software development process that also supports the improvement process. The assessment is then analyzed using Pareto Analysis to determine the priority of improvement. The process of developing software that has been good from the 5 (five) process areas analyzed is in the process area of OPD (Organizational Process Definition), OT (Organizational Training), and PI (Product Integration). While the process areas that do not meet CMMI standards and need to be improved on a priority scale are found in the OPF (Organizational Process Focus), and RD (Requirement Development) process areas with a cumulative value of $44 \%$ for OPF and $68 \%$ for $R D$.
\end{abstract}

Keywords: Software Development, Capability Maturity Model Integration, Pareto Analysis

This work is licensed under a Creative Commons Attribution-ShareAlike 4.0 International License. 


\section{Pendahuluan}

Pesatnya perubahan akibat Teknologi Digital saat ini sangat berpengaruh besar bagi pelaku industri mulai dari industri transportasi, jasa, retail, keuangan dan pemerintah. Di Indonesia, perubahan pola hidup dan bisnis akibat teknologi digital (Digital Disruption) mulai terlihat jelas. Bidang yang langsung merasakan pengaruh tersebut mulai melakukan perubahan model bisnis kearah digital dan otomatisasi. Disrupsi Digital ini akan membawa perubahan besar pada setiap aspek kehidupan istilah Globalisasi 2.0 sangat erat kaitannya akan kuatnya pengaruh teknologi digital pada proses ekonomi, politik, sosial dan bidang kehidupan lainnya.

Seiring berkembangnya perubahan teknologi informasi pada era Digitalisasi ini menuntut banyak organisasi untuk mengembangkan aplikasi-aplikasi yang handal guna mendukung operasionalnya dan meningkatkan pelayanan kepada masyarakat. Banyak manfaat yang dapat diambil oleh organisasi yang mampu menerapkan teknologi informasi dalam bisnis proses mereka. Antara lain yaitu pengurangan waktu dalam pemberian layanan, peningkatan kualitas, fungsional dan kemudahan penggunaan serta peningkatan berkelanjutan yang dilakukan dengan biaya minimum, beberapa keuntungan tersebut pada akhirnya membantu organisasi dalam mencapai visi dan misi mereka. Jumlah manfaat yang didapat organisasi telah mendorong ekspektasi yang meningkat pada peran TI. TI diharapkan tidak lagi menjadi alat penggerak tetapi menjadi bagian yang terintegrasi dalam implementasi strategi bisnis organisasi.

Dalam proses pengembangan aplikasi, perlu dilakukan kualitas kontrol yang baik sehingga dapat menghasilkan suatu aplikasi yang handal dan akurat, dan juga demi keberlangsungan proses pengembangan aplikasi itu sendiri di masa mendatang. Dengan demikian, kualitas tinggi dari perangkat lunak menjadi kebutuhan vital (Widodo, 2016). Untuk mendapatkan perangkat lunak berkualitas tinggi, diperlukan kualitas proses pembuatan perangkat lunak yang baik. Software Engineering Institute (SEI) mengatakan bahwa kualitas suatu sistem atau produk ditentukan oleh kualitas proses dan pemeliharaannya (CMMI Product
Team, 2010). Salah satu alat ukur apakah sebuah aplikasi itu dikembangkan dengan baik, efisien dan terkontrol adalah dengan menggunakan metode Capability Maturity Model Integration (CMMI) level 3.

Perusahaan pengembang perangkat lunak yang dengan sumber daya yang terbatas, biasanya memiliki permasalahan dalam meningkatkan kualitas proses pengembangan perangkat lunak, sehingga masih ada beberapa proyek yang tidak sesuai dengan harapan perusahaan dan klien atau adanya penundaan implementasi proyek karena jumlah sumber daya yang kurang memadai. Perlu adanya strategi dalam mengoptimalkan proses pengembangan perangkat lunak sehingga pengembangan perangkat lunak tidak terlalu tergantung pada orang, tetapi lebih pada proses yang telah distandarisasi. Hal terpenting yang mempengaruhi keberhasilan atau kegagalan sebuah pengembangan perangkat lunak adalah proses pembuatan perangkat lunak (Liou, 2011).

CMMI adalah suatu model proses dan perilaku yang membantu organisasi menyederhanakan peningkatan proses dan mendorong perilaku yang produktif dan efisien yang mengurangi risiko dalam pengembangan perangkat lunak, produk, dan layanan dan merupakan suatu pendekatan perbaikan proses yang memberikan unsur-unsur penting proses efektif bagi organisasi. Praktikpraktik CMMI dipublikasikan dalam dokumendokumen yang disebut model, yang masingmasing ditujukan untuk berbagai bidang yang berbeda (Kneuper, 2008). CMMI menangani jalan mana yang harus ditempuh oleh suatu organisasi untuk bisa mengelola proses yang terpetakan dan memiliki tahapan yang terdefinisikan dengan baik. Asumsi yang berlaku di sini adalah bahwa dalam organisasi yang matang, dimungkinkan untuk mengukur dan mengaitkan antara kualitas produk dan kualitas proses.

Dalam penelitian ini, penulis melakukan tinjauan studi menggunakan buku dan jurnal yang berhubungan dengan tema yang dipilih.

\section{Audit}

Audit menurut Arens (2011) adalah "Pengumpulan dan evaluasi bukti tentang 
informasi untuk menentukan dan melaporkan derajat kesesuain antara informasi itu dan kriteria yang telah ditetapkan" (Arens, 2011).

\section{Pengembangan Perangkat Lunak}

Menurut I. Sommerville, Software Engineering Ninth Edition, (Sommerville, 2011) mengemukakan bahwa: "Pengembangan perangkat lunak adalah serangkaian kegiatan yang bertujuan untuk menghasilkan produk perangkat lunak yang sesuai dengan kebutuhan. Ada empat kegiatan dasar yang umum untuk pengembangan perangkat lunak, yaitu, spesifikasi perangkat lunak, pengembangan perangkat lunak, validasi perangkat lunak dan evolusi perangkat lunak". SPF menyatakan bahwa kerangka kerja pengembangan perangkat lunak dalam membentuk hubungan antara elemen-elemen operasi yaitu berupa alat kebijakan, standar prosedur, proses dan pelatihan (Oslon, 1993).

\section{CMMI (Capability Maturity Model Integration) \\ Capability Maturity Model Integration} (CMMI) adalah pelatihan peningkatan proses dan program penilaian suatu organisasi (CMMI Product Team, 2010). Dikelola oleh CMMI Institute, anak perusahaan ISACA, dikembangkan di Carnegie Mellon University (CMU). Ini diperlukan oleh banyak kontrak Pemerintah A.S., terutama dalam pengembangan perangkat lunak. CMU mengklaim CMMI dapat digunakan untuk memandu peningkatan proses di seluruh proyek, divisi, atau seluruh organisasi. CMMI mendefinisikan tingkat kematangan untuk proses berikut: Awal, Dikelola, Ditentukan, Dikelola Secara Kuantitatif, dan Optimalisasi. Versi 2.0 diterbitkan pada 2018. CMMI terdaftar di Kantor Paten dan Merek Dagang AS oleh CMU.

\section{CMMI for Development (CMMI-DEV)}

Awalnya CMMI membahas tiga bidang yang diminati:

1) Pengembangan produk dan layanan CMMI untuk Pengembangan (CMMIDEV),

2) Pembentukan layanan, manajemen, CMMI untuk Layanan (CMMI-SVC), dan

3) Akuisisi produk dan layanan - CMMI untuk Akuisisi (CMMI-ACQ).
Dalam versi 2.0, ketiga area ini (yang sebelumnya masing-masing memiliki model terpisah) digabung menjadi satu model. CMMI-Dev terdiri dari 22 Area Proses yaitu: CAR (Causal Analysis and Resolution), CM (Configuration Management), DAR (Decision Analysis and Resolution), IPM (Integrated Project Management), MA (Measurement and Analysis), OPD (Organizational Process Definition), OPM (Organizational Performance Management), OPF (Organizational Process Focus), OPP (Organizational Process Performance), OT (Organizational Training), PI (Product Integration), PMC (Project Monitoring and Control), PP (Project Planning), PPQA (Process and Product Quality Assurance), QPM (Quantitative Project Management), RD (Requirements Development), REQM (Requirements Management), RSKM (Risk Management), SAM (Supplier Agreement Management), TS (Technical Solution), VAL (Validation), VER (Verification).

Bergantung pada bidang minat (akuisisi, layanan, pengembangan) yang digunakan, area proses yang dikandungnya akan bervariasi. Area proses adalah area yang akan dicakup oleh proses organisasi. Tabel di bawah ini mencantumkan tujuh belas area proses inti CMMI yang ada untuk semua bidang CMMI yang diminati dalam versi 1.2 (Kautsarina, 2011)

Tabel 1. Area Proses dan Kategori 


\begin{tabular}{|l|l|}
\hline \multicolumn{1}{|c|}{ PROCESS AREA } & \multicolumn{1}{c|}{ CATEGORY } \\
\hline Maturity Level 2 - Managed & \\
\hline CM - Configuration Management & Support \\
\hline MA - Measurement and Analysis & Support \\
\hline PMC - Project Monitoring and Control & Project Management \\
\hline PP - Project Planning & Project Management \\
\hline PPQA - Process and Product Quality Assurance & Support \\
\hline REQM - Requirements Management & Engineering \\
\hline SAM - Supplier Agreement Management & Project Management \\
\hline Maturity Level 3 - Defined & \\
\hline DAR - Decision Analysis and Resolution & Support \\
\hline IPM - Integrated Project Management & Project Management \\
\hline OPD - Organizational Process Definition & Process Management \\
\hline OPF - Organizational Process Focus & Process Management \\
\hline OT - Organizational Training & Process Management \\
\hline PI - Product Integration & Engineering \\
\hline RD - Requirements Development & Engineering \\
\hline RSKM - Risk Management & Project Management \\
\hline TS - Technical Solution & Engineering \\
\hline VAL - Validation & Engineering \\
\hline VER - Verification & Engineering \\
\hline Maturity Level 4 - Quantitatively Managed & \\
\hline OPP - Organizational Process Performance & Process Management \\
\hline QPM - Quantitative Project Management & Project Management \\
\hline Maturity Level 5 - Optimizing & \\
\hline CAR - Causal Analysis and Resolution & Support \\
\hline OPM - Organizational Performance Management & Process Management \\
\hline Smb & 2010 - \\
\hline
\end{tabular}

Sumber: CMMI Product Team (2010)

\section{SCAMPI}

SCAMPI (Standard CMMI Appraisal Method for Process Improvement) terdiri dari tiga kelas yaitu kelas $A$, kelas $B$, dan kelas $C$, yang dibedakan berdasarkan tingkat akurasi dan upaya yang dihasilkan (Hayes et al., 2005) SCAMPI-A adalah metode yang paling ketat dan satu-satunya metode yang dapat menghasilkan nilai (skor) dan penilaian yang diperlukan untuk memimpin penilaian bersertifikat. Biasanya biaya yang dikeluarkan untuk SCAMPI-A cukup besar. SCAMPI-B adalah metode yang kurang formal daripada SCAMPI-A, kegiatannya lebih sedikit dari SCAMPI-A. Dengan menerapkan SCAMPI-B, organisasi dapat memprediksi hasil yang diperoleh saat melakukan SCAMPI-A. Metode ini tidak membutuhkan petunjuk penilaian. SCAMPI-C lebih pendek, fleksibel, dan lebih murah dengan SCAMPI-A dan SCAMPI-B. Keputusan dari SCAMPI-C biasanya digunakan untuk mengukur kesiapan organisasi sebelum menerapkan CMMI. Dengan melakukan penilaian SCAMPI-C, dapat dengan mudah mendapatkan celah dari proses yang telah dilakukan oleh organisasi dibandingkan dengan praktik terbaik CMMI (W. Hayes, G. Miluk, 2015). Lingkup SCAMPI-
C juga dapat disesuaikan dengan penilaian objektif.

Untuk SCAMPI kelas C, kebutuhan untuk melakukan penilaian mengurangi jumlah usaha dan biaya, tetapi mengurangi akurasi dan keandalan juga lebih rendah. SCAMPI-C bahkan memungkinkan pengurangan jumlah proyek yang akan diselidiki menjadi nol dan hanya melakukan proses penilaian yang terdokumentasi standar, bukan implementasi proyek.

\section{METODOLOGI PENELITIAN}

\section{Objek Penelitian}

Berdasarkan kelas tabel perbandingan SCAMPI, untuk SCAMPI-C, jumlah minimum sumber data adalah 1 (satu). Dalam penelitian ini sumber data akan diambil dari dua proyek pengembangan perangkat lunak yang telah selesai.

Tabel 2. Perbandingan Kelas SCAMPI

\begin{tabular}{|l|l|l|l|}
\hline & Kelas A & Kelas B & Kelas C \\
\hline $\begin{array}{l}\text { Jumlah tim yang } \\
\text { dievaluasi }\end{array}$ & $8-10$ & $3-4$ & $1-2$ \\
\hline Waktu evaluasi & 10 hari & $3-4$ hari & $1-2$ hari \\
\hline Sumber data minimum & 3 & 2 & 1 \\
\hline $\begin{array}{l}\text { Keandalan dan } \\
\text { kesuksesan }\end{array}$ & Tinggi & Sedang & Rendah \\
\hline $\begin{array}{l}\text { Upaya dan biaya yang } \\
\text { dibutuhkan }\end{array}$ & Tinggi & Sedang & Rendah \\
\hline Wawancara langsung & Ya & Ya & Tidak \\
\hline SCAMPI & A & B & C \\
\hline
\end{tabular}

Sumber: Appraisal Requirements for CMMI, Version 1.1

Untuk memilih proyek yang akan dievaluasi, yang merupakan proyek pengembangan perangkat lunak khas perusahaan, wawancara akan dilakukan kepada Direktur dan Kepala Divisi IT perusahaan.

\section{Kerangka Pemikiran}

Berdasarkan tinjauan pustaka, untuk meningkatkan keberhasilan suatu proyek pengembangan perangkat lunak, maka kita harus meningkatkan proses yang digunakan. Meningkatkan proses pengembangan dapat merujuk pada praktik terbaik CMMI-Dev seperti pada gambar 1 berikut. 


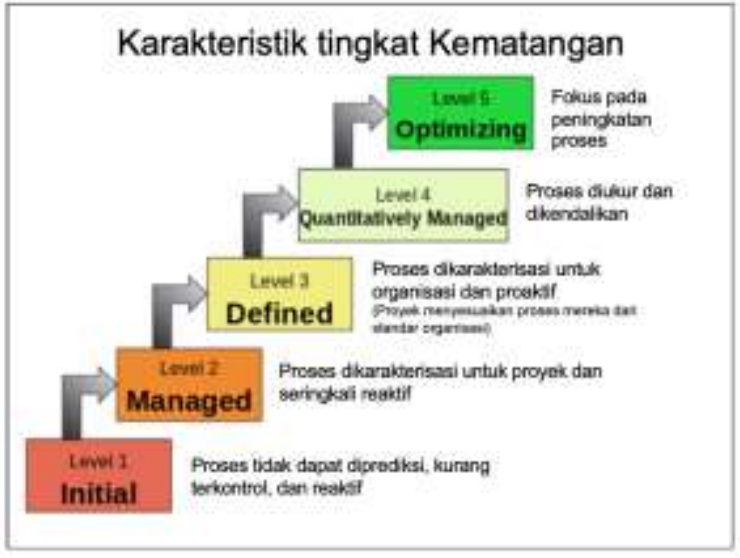

Gambar 1. Karakteristik tingkat kematangan pada CMMI-Dev

Operasi pengembangan perangkat lunak mengacu pada kerangka proses pengembangan perangkat lunak. Kerangka kerja sudah disesuaikan dengan implementasi area proses CMMI. Untuk menentukan bagian mana yang perlu diperbaiki, maka diperlukan sebuah metode untuk mengukurnya.

Untuk melakukan pengukuran akan menggunakan metode SCAMPI. Dalam penelitian ini, pengukuran hanya untuk menentukan bagian mana yang perlu diperbaiki dan bukan untuk mengukur skor tingkat kematangan. Seperti yang dijelaskan masing-masing, maka SCAMPI kelas $C$ yang akan dipilih.

Berdasarkan hasil pengukuran, akan menentukan kelemahan dan perbaikan apa yang perlu dilakukan sesuai dengan referensi CMMI-Dev dan SPF (Software Process Framework). Analisis pareto kemudian akan digunakan untuk membuat prioritas perbaikan.

\section{Tahap Penelitian}

Tahapan penelitian pada Gambar 2, dimulai dengan mendefinisikan masalah yang akan diperiksa bersama dengan batas dan ruang lingkup. Kemudian menentukan tujuan dan manfaat penelitian. Setelah itu melakukan studi literatur dan mengambil kasus untuk diselidiki.

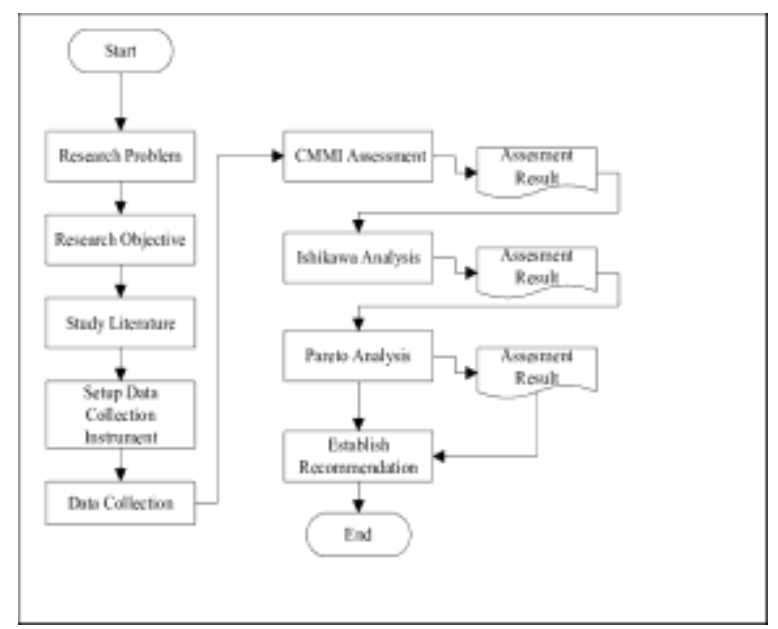

Gambar 2. Tahap Penelitian

Pengumpulan data dilakukan setelah menyiapkan instrumen pengumpulan data. Dengan mengacu pada CMMI-Dev level 3, ada 12 Area Proses yang harus dievaluasi. Tetapi dalam penelitian ini hanya 5 Area Proses dari data yang dikumpulkan akan diperiksa, yang berhubungan langsung dengan proses pengembangan perangkat lunak, yaitu OPD (Organizational Process Definision) yang terdiri dari total 2 Tujuan Spesifik (Specific Goal) dan 8 Praktik Khusus (Specific Practice), OPF (Organizational Process Focus), terdiri dari total 3 Tujuan Spesifik dan 9 Praktik Khusus, OT (Organizational Training), terdiri dari total 2 Tujuan Spesifik dan 7 Praktik Khusus, PI (Product Integration), terdiri dari total 3 Tujuan Spesifik dan 9 Praktek Khusus, RD (Requirements Development), terdiri dari total 3 Tujuan Spesifik dan 10 Praktek Khusus.

Setelah data cukup tersedia, kemudian melakukan penilaian CMMI dengan melakukan pemrosesan data dari hasil pengamatan ini dengan menggunakan Alat PST. Dari penilaian ini akan diperoleh proses CMMI yang sesuai dan proses yang perlu ditingkatkan. Untuk proses yang perlu diperbaiki, akan dianalisis menggunakan diagram Ishikawa dan merujuk ke SPF untuk menemukan akar masalah. Untuk menentukan prioritas perbaikan proses, akan digunakan diagram Pareto, dengan mengacu pada SPF. Akhirnya, dibuat rekomendasi berdasarkan hasil pengolahan data secara keseluruhan.

\section{Metode Pengumpulan Data}


Metode pengumpulan data dalam penelitian ini terdiri dari wawancara, observasi proses pengembangan perangkat lunak, dan analisis dokumen yang terkait dengan proses pengembangan perangkat lunak di perusahaan pengembang perangkat lunak dengan sumber daya terbatas.

\section{Metode Pemrosesan Data}

Data yang diperoleh dari wawancara, observasi dan analisis dokumen akan digunakan sebagai referensi untuk melakukan analisis data. Analisis akan dilakukan berdasarkan prosedur yang digunakan untuk melakukan penilaian area proses dengan menggunakan metode SCAMPI-C. Dengan melakukan penilaian akan diperoleh praktik mana yang dalam kondisi baik dan praktik mana yang perlu ditingkatkan. Untuk latihan yang perlu ditingkatkan akan mencari akar masalah dengan menggunakan Analisis Ishikawa. Selanjutnya, untuk sebelum perbaikan akan dianalisis menggunakan analisis Pareto. Akhirnya akan dibuat rekomendasi untuk perbaikan.

\section{Hasil dan Pembahasan}

\section{Pengumpulan Data}

Wawancara dilakukan untuk pemilihan proyek yang akan dievaluasi. Berdasarkan hasil wawancara mengenai pemilihan proyek yang akan dievaluasi, maka diambil proyek pengembangan perangkat lunak untuk proyek Pocketbank Mobile Banking dan Pocketbank TPE (Transaction Processing Engine). Data yang dikumpulkan dalam bentuk dokumen proyek dan hasil pengamatan pada proses pengembangan perangkat lunak pada proyekproyek ini.

\section{Hasil Penilaian Area Proses menggunakan SCAMPI-C}

Untuk menilai area proses menggunakan Alat PST (PIID and SCAMPI Tool) dari Dr. Kneuper, artefak pada proyek yang dipilih digunakan untuk mengisi kembali alat tersebut. Dalam studi ini, artefak tersedia dalam bentuk dokumen proyek. Untuk area proses dengan praktiknya yang tidak memiliki dokumen sebagai bukti objek, praktik tersebut belum berhasil diterapkan pada proyek dan akan ditemukan dengan latar belakang kuning. Jika belum diimplementasikan, akan ditemukan dengan latar belakang merah. Semua temuan akan dihitung untuk setiap area proses. Jumlah temuan untuk setiap area proses dapat dilihat pada Tabel 3. Temuan terbanyak adalah dalam OPF (11 temuan) dan temuan terkecil di OPD (2 temuan).

Tabel 3. Hasil Temuan Pada Setiap Area Proses

\begin{tabular}{|l|c|}
\hline \multicolumn{1}{|c|}{ Area Proses } & Jumlah Temuan \\
\hline Organizational Process Focus (OPF) & 11 \\
\hline Requirements Development (RD) & 6 \\
\hline Product Integration (PI) & 3 \\
\hline Organizational Training (OT) & 3 \\
\hline Organizational Process Definition (OPD) & 2 \\
\hline
\end{tabular}

\section{Hasil Analisis Ishikawa}

Menggunakan Analisis Ishikawa untuk setiap temuan yang dikaitkan dengan SPF, setiap temuan dianalisis apakah dalam kategori prosedur, proses, kebijakan, atau standar SPF. Semua temuan akan dihitung untuk setiap kategori.

Jumlah temuan untuk setiap kategori dirangkum dalam Tabel 4. Temuan terbanyak ada pada kategori prosedur (10 temuan) dan temuan terkecil dalam kategori standar (1 temuan).

Tabel 4. Temuan Pada Setiap Kategori SPF

\begin{tabular}{|l|c|}
\hline \multicolumn{1}{|c|}{ Kategori SPF } & Jumlah Temuan \\
\hline Prosedur & 10 \\
\hline Proses & 8 \\
\hline Kebijakan & 6 \\
\hline Standar & 1 \\
\hline
\end{tabular}

\section{Hasil Analisis Pareto}

Berdasarkan analisis Ishikawa untuk setiap kategori SPF, jumlah temuan setiap kategori dapat diringkas untuk digunakan pada analisis pareto berdasarkan kategori SPF. Temuan diurutkan dari yang paling banyak ke yang paling sedikit, kemudian setiap kategori dihitung jumlahnya, persentase penemuan kumulatif dan dapat dilihat pada Tabel 5.

Tabel 5. Analisa Pareto Berdasarkan Kategori SPF

\begin{tabular}{|l|c|c|c|}
\hline Kategori SPF & $\begin{array}{c}\text { Jumlah } \\
\text { Temuan }\end{array}$ & Kumulatif & $\begin{array}{c}\% \\
\text { Kumulatif }\end{array}$ \\
\hline Prosedur & 10 & 10 & 40 \\
\hline Proses & 8 & 18 & 72 \\
\hline Kebijakan & 6 & 24 & 96 \\
\hline
\end{tabular}




\begin{tabular}{|l|l|l|l|}
\hline Standar & 1 & 25 & 100 \\
\hline
\end{tabular}

Berdasarkan data pada Tabel 5 maka dapat dibuat diagram Pareto seperti yang ditunjukkan pada Gambar 3.

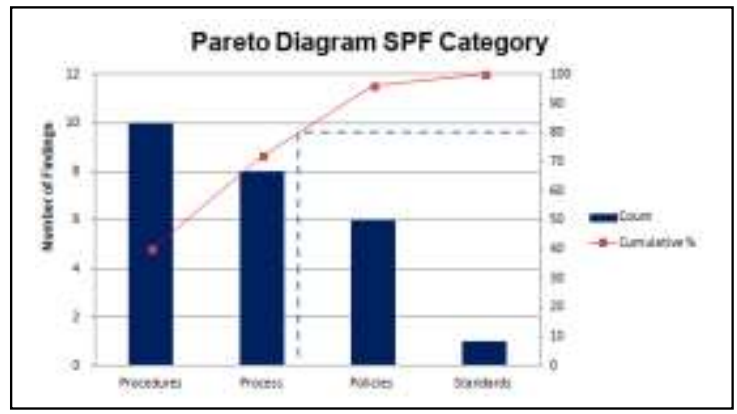

Gambar 3. Diagram Pareto Berdasarkan Kategori SPF

Berdasarkan diagram Pareto pada Gambar 2, prioritas perbaikan proses oleh kategori SPF adalah kategori prosedur dan kemudian diikuti oleh kategori proses.

Berdasarkan analisis Ishikawa untuk setiap area proses, jumlah temuan untuk setiap area proses dapat dirangkum untuk digunakan pada analisis Pareto berdasarkan area proses. Temuan diurutkan dari yang paling banyak ke yang paling sedikit, kemudian setiap area proses dihitung dari jumlah, persentase penemuan kumulatif dan dapat dilihat pada Tabel 6.

Tabel 6. Analisa Pareto Berdasarkan Area Proses

\begin{tabular}{|l|c|c|c|}
\hline Area Proses & $\begin{array}{l}\text { Jumlah } \\
\text { Temuan }\end{array}$ & Kumulatif & $\begin{array}{c}\% \\
\text { Kumulatif }\end{array}$ \\
\hline $\begin{array}{l}\text { Organizational Process } \\
\text { Focus (OPF) }\end{array}$ & 11 & 11 & 44 \\
\hline $\begin{array}{l}\text { Requirements Definition } \\
\text { (RD) }\end{array}$ & 6 & 17 & 68 \\
\hline $\begin{array}{l}\text { Product Integration (PI) } \\
\begin{array}{l}\text { Organizational Training } \\
\text { (OT) }\end{array}\end{array}$ & 3 & 20 & 80 \\
\hline $\begin{array}{l}\text { Organizational Process } \\
\text { Definition (OPD) }\end{array}$ & 2 & 25 & 100 \\
\hline
\end{tabular}

Berdasarkan data pada Tabel 6 maka dapat dibuat diagram Pareto seperti yang ditunjukkan pada Gambar 4.

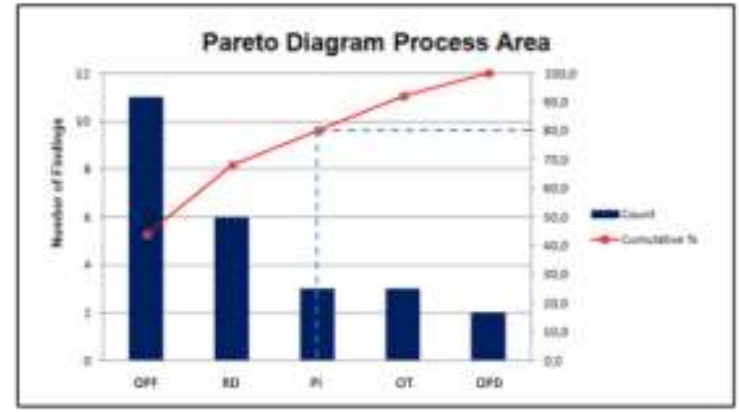

Gambar 4. Diagram Pareto Berdasarkan Area Proses

Berdasarkan diagram Pareto pada Gambar 3, prioritas peningkatan proses berdasarkan area proses secara berurutan adalah OPF (Organizational Process Focus) dan RD (Requirements Development).

\section{Rekomendasi}

Dengan menggabungkan analisis Pareto berdasarkan kategori SPF dan analisis Pareto berdasarkan area proses, dapat dijadikan rekomendasi untuk perbaikan proses yang dapat dilakukan di perusahaan.

Rekomendasi pertama adalah untuk menetapkan prosedur perekaman pengujian modul, prosedur penandatanganan hasil pengujian, dan prosedur perencanaan pengujian. Kemudian melakukan pelatihan tentang cara melakukan QA, menggunakan praktik terbaik yang telah dicapai. Setelah itu menetapkan prosedur mendefinisikan persyaratan perangkat lunak, prosedur mendefinisikan perencanaan kebutuhan perangkat lunak, dan prosedur evaluasi persyaratan pengembangan perangkat lunak.

Rekomendasi berikutnya adalah melakukan pelatihan tentang definisi persyaratan perangkat lunak, pelacakan persyaratan perangkat lunak dua arah.

Rekomendasi terakhir adalah menetapkan prosedur pemantauan dan pengendalian proyek kemudian melakukan pelatihan pemantauan dan pengendalian proyek.

\section{Kesimpulan}

Penelitian ini mengambil 2 tim proyek implementasi pengembangan perangkat lunak yang sedang berjalan. Penelitian ini dilakukan karena adanya masalah 
keterlambatan penyelesaian atas pengembangan perangkat lunak yang tidak sesuai dengan jadwal yang telah ditentukan. Setelah evaluasi proses pengembangan perangkat lunak di perusahaan dengan sumber daya terbatas menggunakan SCAMPI-C berdasarkan CMMI-Dev versi 1.3 dengan level 3 dan dianalisis dengan analisis Pareto dan analisis Ishikawa, dapat disimpulkan bahwa beberapa proses pengembangan perangkat lunak sudah baik dan beberapa kebutuhan untuk ditingkatkan. Proses pengembangan perangkat lunak yang sudah baik adalah proses yang terdapat di bidang OPD (Organizational Process Definition), OT (Organizational Training), dan PI (Product Integration). Sementara untuk area proses yang masih perlu ditingkatkan adalah proses yang terdapat di bidang OPF (Organizational Process Focus) dengan nilai kumulatif $46 \%$ dan RD (Requirements Development) dengan nilai kumulatif $68 \%$.

\section{REFERENSI}

Arens, A. (2011). JASA AUDIT DAN ASSURANCE Pendekatan Terpadu (Adaptasi Indonesia). In Jasa Audit dan Assurance Pendekatan Terpadu (Adaptasi Indonesia).

CMMI Product Team. (2010). CMMI for Development, Version 1.3. Software Engineering Process Management Program. https://doi.org/CMU/SEI-2010TR-033 ESC-TR-2010-033

Hayes, W., Miluk, G., Ming, L., Glover, M., Of The Scampi B, M., \& Project, C. (2005). Handbook for Conducting Standard CMMI Appraisal Method for Process Improvement (SCAMPI) B and C Appraisals, Version 1.1 (HANDBOOK CMU/SEI-2005-HB-005). In Sei.
Kautsarina. (2011). Penilaian Tingkat Kematangan Tiga Proses Area Level 2 CMMI Versi 1.2 pada Small Independent Software Vendor di Indonesia (Studi Kasus: Inovasia). Widyariset, 14, $n$.

Kneuper, R. (2008). CMMI: improving software and systems development processes using capability maturity model integration (CMMI-DEV).

Liou, J. C. (2011). On improving CMMI in an immature world of software development. Journal of Information Science and Engineering.

Oslon, T. G. (1993). NoA Software Process Framework for the SEI Capability Maturity Model: Repeatable Level,. Software Engineering Institute, Pittsburgh.

Sommerville, I. (2011). Ingenierìa de Software. In Software Engineering.

W. Hayes, G. Miluk, L. M. and M. G. (2015). Handbook for Conducting Standard CMMI Appraisal Method for Process Improvement (SCAMPI) $B$ and $C$ Appraisals, Version 1.1. Hanscom: Carnegie Mellon University.

Widodo, W. (2016). EVALUASI PROSES PENGEMBANGAN PERANGKAT LUNAK PADA VIRTUAL TEAM DEVELOPMENT MENGGUNAKAN CMMI Versi 1.3. Jurnal Informatika. https://doi.org/10.26555/jifo.v10i1.a3345 